\title{
Divergent and Similar Experiences of 'Gating' in South Africa: Johannesburg, Durban and Cape Town
}

\author{
Charlotte Lemanski \& Karina Landman \& \\ Matthew Durington
}

\begin{abstract}
The last 20 years has witnessed an explosion not only in the growth of private residential territories throughout the world, but also in the literature addressing them. The majority of research is centred on experiences in the United States and Latin America (although studies elsewhere are increasing) and suffers from a tendency to homogenise the processes and consequences of gating as synonymous whether experienced in Los Angeles, New York, Mexico City or São Paulo. Whilst axiomatic to state the unlikelihood of identical trends in such differing contexts, the absence of such a statement in the literature is significant. This paper addresses the social and spatial phenomenon of residential gated communities in three of South Africa's major cities: Johannesburg, Durban and Cape Town. Detailed background and discussion regarding the development and experience of 'gating' in each city is analysed, emphasising the uniqueness of each city's gating experience. These indications, that gating is not a universal experience despite some common themes, serve to counter the homogenous discourse in both popular and academic parlance throughout the world and within South Africa. In addition, particular concerns related to the growth of residential forms based on exclusion and privatisation within the South African context, are considered. In essence, we conclude that while 'gating' may be an individually rational decision in the context of South Africa's growing crime, its collective consequences produce a divided city, at odds with post-apartheid ideals of unity and equality.
\end{abstract}

Keywords Gated community · Johannesburg · Durban · Cape Town · South Africa · Private residential territories

\section{Introduction}

The last 20 years have witnessed an explosion not only in the growth of private residential territories throughout the world, but also in the literature addressing them. 
Functioning in an increasingly "risk society" (Beck 1992), residents and corporations across the globe have responded to factors such as rising violent crime, the migration of 'difference' into close proximity and decreasing state provision of security and other services by choosing reliance on the private. From Los Angeles to Rio de Janeiro and Johannesburg, a pattern has emerged of electrified fences, tall and impenetrable walls and permanent security guards employed to protect and secure residential, commercial and corporate zones from dangerous 'outsiders'. Although these visions, of the wealthy incarcerated in islands of privatised safety that are distanced from the rest of the city, have gathered significant momentum both in academic and popular literature based on diverse empirical sites, in fact, there is no singularly uniform experience of gating. Through an exploration of the history and incidence of residential gating in three cities of South Africa, this paper challenges the homogenuity of existing empirical research, indicating the need to acknowledge diverse experiences to ensure suitable theoretical and policy responses. In addition, particular concerns related to the growth of residential forms based on exclusion and privatisation within the South African context are considered.

The label 'gated communities' masks a multitude of different territorial strategies, ranging from total security estates (residential or commercial) with impenetrable boundaries and 24-h security guards monitoring access and patrolling the interior, sectional title developments and blocks of apartments with perimeter fencing and a

gate accessible by remote control, the 'booming-off' of existing streets (enclosed neighbourhoods) and everything in between. Despite multiple labels and manifestations, gated communities are defined by their perimeter boundary (e.g., fence, wall) and restricted access (e.g., security guard, remote-controlled gate). This paper addresses the social, spatial and political phenomena of residential gated communities in three of the major cities of South Africa: Johannesburg, Durban and Cape Town. ${ }^{1}$

The majority of literature on gated communities emphasises their negative impacts, with evidence principally from the United States and Latin America (although research from elsewhere is growing) used as representative of trends throughout the world. Such research typically stresses that the consequences of an increase in private territoriality is a cost for the rest of society and the city. These costs manifest in two principal forms; the

exclusion of individuals and the fragmentation of the city. In particular, gated communities are criticised for creating exclusionary spaces, increasing residential segregation, restricting freedom of movement and exacerbating social divides (e.g. Blakely and Snyder 1997; Caldeira 1999, 2000; Davis 1992; Low 2003; Marcuse 1997). Indeed, only a minority of researchers reveal any positive function; for

\footnotetext{
${ }^{1}$ The focus is on developments where each homeowner has a single title deed but lives within a group environment in which the responsibility for security is shared, and not sectional title complexes (e.g., townhouse developments or apartment blocks) where the complex is owned by the body corporate. In other words, this research addresses residential security estates and enclosed neighbourhoods.
} 
example, Charles Jencks (1993:93) praises Los Angeles' gated communities for protecting threatened groups from ethnic conflict, Salcedo and Torres (2004) indicate the role played by Chile's gated communities in facilitating functional integration (e.g., employment) and improved understanding with their poorer neighbours, and Fred Foldvary (1994) justifies the economic efficiency of gated communities. In addition, developers, property agents and residents not surprisingly all promote the positive aspects of gated communities, principally based on personal experiences and perspectives. However, such deviances from the overwhelming trend to vilify gated communities in academic and popular parlance are rare.

South Africa's gated communities are similarly criticised for entrenching existing patterns of socio-spatial urban fragmentation and protecting the wealthy at the expense of the poor (e.g., Ballard 2004; Bremner 2004; Durington 2006; Hook and Vrdoljak 2002; Jürgens et al. 2003; Landman 2000a, b, 2004; Lemanski 2004, 2006a, b). Although representative of worldwide gated community literature, in South Africa, concerns regarding these exclusionary territories are exacerbated by fears that they effectively recreate the apartheid city and thwart post-apartheid goals of urban integration and inclusion. Indeed, by retreating from public spaces into private enclaves and allowing access only to those with the necessary socioeconomic credentials, a new form of urban apartheid is emerging (Lemanski 2004), albeit one in which class rather than race determines access to the city (although in contemporary South Africa, class remains closely linked to race). Furthermore, a city composed of such "urban forts" (Landman 2000b) promotes inequality and separation, both of which are irreconcilable with the democratic values of universality and equality, crucial to South Africa's post-apartheid transformation.

The South African Human Rights Commission report, published in 2005, declared the erection of boom gates and other measures of enclosure a violation of human rights (SAHRC 2005). Their argument follows that the existence of these spaces restricts access and is therefore a direct violation of the newly established ethos of the country. Whereas restriction to public spaces is problematic in any society, it is especially poignant in South Africa given its parallels with apartheid's foundation of controlling access to spaces (through pass laws and other restrictions). Thus, the constitution of the 'New' South Africa provides freedom of access for all citizens. Although gated communities do not represent class or racial exclusion in the apartheid sense, they do restrict access to nonresidents (irrespective of race or class), although nonresidents are most likely to be poor and black. ${ }^{2}$ While gated communities are condemned by the South African Human Rights Commission, many accept them as a 'necessary evil', limiting the emigration of South Africa's business-owning (predominantly White) population. ${ }^{3}$

\footnotetext{
${ }^{2}$ The apartheid racial classifications of African, Coloured (mixed heritage), Indian (Asian descent) and White (European) are used throughout this paper. However, apartheid's 'African' label is updated to 'Black African' in recognition that the other groups are also Africans ('Black African' is also the term adopted by the census in 2001). The term 'black' (lowercase) is used in reference to all non-Whites.

${ }^{3}$ South Africa has undergone significant emigration of professionals in the past 15 years, predominantly to western countries such as the UK and Australia (e.g., 16,165 "self-declared" South African emigrants left the country in 2003 alone, Pretoria News 2006). For more on this 'brain drain' see work by the Southern African Migration Project (SAMP): http://www.queensu.ca/samp/.
} 
Indeed, research in South Africa indicates that living in a private territory is not solely a residential decision, but also reflects a desire to remove oneself from civic engagement and abstain from the responsibilities of civil society (Hook and Vrdoljak

2002). Richard Ballard (2004) labels this "semigration", meaning that although citizens remain in South Africa rather than emigrate, they separate themselves from its increasing 'African-ness' and create islands of modern Western culture in the midst of an African nation, albeit within walls and gates. Irrespective of whether the goal is a 'Western' utopia, or just an exclusive space, it appears that gated communities serve as a means for South Africans to distance themselves from society, to ignore national goals (such as unity and integration) and create an "alternative representation of reality" in which "one's right to property and personal privacy (rather than one's civic duty) remain sacrosanct" (Hook and Vrdoljak 2002: 216 and 198). Thus, gating in South Africa is perceived as a means to wield one's own power, as a private property owner, rather than submit to the state, as a citizen.

The global and South African narratives on gated communities and the privatisation of space are used to frame the development of gating in three cities throughout this paper. Furthermore, the homogeneity of most literatureis challenged by indications that vast differences exist in each city's incident of, and response to, gating even within a single nation. While not suggesting that prior research on gated communities is erroneous, this paper identifies and compensates for the tendency to homogenise the processes and consequences of gating as synonymous whether experienced in Los Angeles, New York, Mexico City, São Paulo or Johannesburg. While axiomatic to state the unlikelihood of identical trends in such differing contexts, the absence of such a statement in the literature is significant. Experiences of gated communities differ at various scales, for example the individual, household and estate, operating in wider processes within the suburb, city, region and nation. By providing detailed background regarding the development of gating in three of South Africa's cities, this paper emphasises the uniqueness of each city's gating experience, indicating that gating is not a universal experience despite some common themes. This city-level focus does not seek to homogenise at the gated estate scale, or ignore diversities within each city, but instead illustrates the differences between cities in terms of urban demographics, history, economics and policy, and their consequent impact on gating trends for each city. This serves to counter the homogenous discourse in both popular and academic parlance throughout the world and within South Africa.

This research is based on in-depth fieldwork undertaken in selected gated communities in Johannesburg, Durban and Cape Town. The Johannesburg research is based on two qualitative case studies, an enclosed neighbourhood and a large security estate, undertaken in 2003; and a detailed review of the proceedings from public hearings conducted by the municipality at the same time. The case study research was conducted through semi-structured interviews, spatial analysis of four neighbourhoods, direct observation in the neighbourhoods and documentation review. The Durban research was conducted in one gated community and surrounding institutional entities using participant observation and other ethnographic methods from 2003-2006. The Cape Town research is based on two blocks of fieldwork: firstly in a single security estate in 2004, and secondly in a number of different types of security estates throughout 2006. In both periods of fieldwork, semi-structured interviews were conducted with residents, complex managers, 
developers and city officials. Although empirically grounded, the focus on in-depth research in each estate rather than covering a wide breadth of case studies ensures that the findings are indicative of trends rather than necessarily conclusive.

\section{Gated Communities and Privatisation}

Gated communities are both the result of and impact on increasing patterns of privatisation in contemporary cities. These patterns broadly encompass the privatisation of public space, service delivery and local urban governance.

\section{Privatisation of Public Space}

The term public space is generally accepted to refer to the streets, sidewalks, parks and plazas that are accessible and open to all people in a particular area. Privatisation of public spaces is now a worldwide phenomenon, characterised by the spread of privately governed and secured neighbourhoods, often called gated communities (Glasze et al. 2006).

There are multiple conceptualisations of urban public space due to the multidisciplinarity of the subject, recognised by several scholars seeking to capture a suitable definition (Low 1996, 2003; Madanipour 2003). The issue is further complicated in discussions of the 'privatisation' of public space. The value of public space and the endangerments of privatisation are frequently cited debates within the critique of contemporary urbanism. However, 'public space' and 'privatisation' are very vague analytical categories, and it often remains unclear what is privatised and why this poses a challenge within cities. Studies on the privatisation of public space dichotomise the public and private realm and often focus uni-dimensionally on material changes in space, thus overlooking the more complex sociopolitical changes associated with private neighbourhoods (Glasze et al. 2006). This paper calls for, and to some extent provides, a balanced and multifaceted enquiry into the privatisation of space and its multidimensional consequences that considers variations within different types of urban developments and between cities.

In general, the privatisation of space refers to contexts in which previously public spaces (whether traditionally or in a particular context) have been closed off for use by the general public and are only available for exclusive use by the residents or members of a "club" (Webster and Glazse 2006). For example, in Latin America, the public cannot access numerous gated communities and, as a result, part of the city has become enclosed and locally governed (Janoschka and Borsdorf 2006).

\section{Privatisation of Service Delivery}

A general lack of trust in local or metropolitan municipalities and fear of weak or absent public service delivery, has facilitated a trend whereby those with the financial means opt to provide their own services, through privatisation. Webster (2001:152) comments 
that apart from security, an important reason for gated communities is residents wanting to take control of their own residential environments and secure the provision of their own choice of civil services. Frantz (2000) also highlights the search for greater efficiency and maintains that this coincides with public spending cutbacks in the USA, leading citizens to opt for private provision of services (Ibid:112).

Consequently, a range of services traditionally provided by the state are now privatised, most notably security and neighbourhood maintenance. The growing privatisation of security services is a global phenomenon, raising many issues regarding the powers given to private security guards, their accountability and the impact on security in general. While the police are accountable to the government and public, it is not always clear who regulates private security guards and security companies (Benit-Gbaffou 2008). This is especially critical in transitional societies where wealthy citizens (including the business sector) often respond to the threat of crime by employing private security agencies (giving rise to increased privatisation of policing). Private security ${ }^{4}$ is a business, and is thus directly accountable to its paying clients. The danger is thus, particularly in transitional societies, that responses to crime, including a growing private security force, will become increasingly militarised. The possible consequences have caused many writers, including Shearing and Kempa (2000) and Shaw (2002) to warn that the development of sophisticated private security industries in transitional countries, including South Africa, should be viewed with concern.

\section{Privatisation of Urban Governance}

Coinciding with the privatisation of public space and services is the establishment of so-called "shadow governments" (micro-governments) to oversee these services and ensure their efficiency (Frantz 2000:112). Webster (2001) identifies many forms of contemporary micro-government, including private residential communities (cooperatives, homeowners' associations and condominiums), retail communities (leisure complexes) and industrial communities (industrial parks). These private municipal governments or micro-governments encompass a wide range of functions. For example, they supply civic goods (such as protection, cleanliness and environmental improvements) and represent those individuals or businesses in a locality that voted for a management body to manage and control affairs (McKenzie 1994; Webster 2001). Consequently, a new kind of governing institution that resembles a private city is spreading rapidly, mainly because it has suited the short-term needs of developers and some local governments (McKenzie 2006).

Micro-governments embody a new form of collective local power that facilitates innovative mechanisms of local control. This might be different in different types of gated area. Some are based on collective local power, while others are private companies managing an area with minimal resident contribution. It may also depend on the different political and economic context of each country or city.

South African cities are increasingly characterised by the privatisation of public space, security and governance. This raises a number of questions related to the broader debate on gated communities and privatisation based on a number of assumptions. Firstly, it is often assumed that all types of gated communities are the 


\footnotetext{
${ }^{4}$ Private security is one type of a non-state form of policing and is common among the wealthy in transitional countries. At the other end of the spectrum is vigilantism, often initiated by, but not restricted to, the poor (Shaw 2002; Landman 2003).
}

same and that they are therefore implemented and managed in the same way. This is however, not the case, not even in a single country. Given this, this paper will highlight a number of differences and consequently the various implications for privatisation in South Africa.

\section{National Survey on Gated Communities}

Residential gated communities in South Africa are broadly categorised as enclosed neighbourhoods and security villages. Enclosed neighbourhoods exist when a suburb/street erect boom gates to control and limit access to their already-established area, whereas security villages are new housing areas constructed by private developers with a perimeter wall and security-controlled access.

A national survey conducted in $2002^{5}$ indicated the highest numbers of enclosed neighbourhoods in the Gauteng province, which hosts the metropolitan municipalities of Tshwane (previously named Pretoria) and Johannesburg. Although two municipalities in the Western Cape (City of Cape Town and Mossel Bay) also indicated high numbers of enclosed neighbourhoods, in fact, enclosed neighbourhoods have not developed in the Western Cape, and it seems likely that these figures reflect misunderstandings. ${ }^{6}$ Furthermore, although e'Thekweni (including Durban) officials indicated in the survey that no enclosed neighbourhoods exist within their boundaries (because they are prohibited), follow-up interviews with officials indicated the presence of several illegal neighbourhood closures. The distribution of security estates is broader. Both municipalities with and without enclosed neighbourhoods reported high numbers of security estates, such as the cities of Johannesburg, Tshwane and Durban, in addition to Cape Town and tourist coastal towns in the Western Cape.

It becomes evident that the different regions and cities of South Africa have experienced diverse gated community typologies. For example, while the highest concentration of security villages are in Gauteng and the Western Cape, followed by e'Thekweni, enclosed neighbourhoods are dominant only in Gauteng. The reasons for these differences and their impact on the city are explored through a discussion of gating in Johannesburg, Durban and Cape Town.

\section{Historical Context}

The differing urban histories of each city are likely to play a vital role in determining the nature of gating that has emerged in recent years. Although all three cities were 


\footnotetext{
${ }^{5}$ The survey was conducted through postal questionnaires sent to all local and metropolitan municipalities (237) in South Africa to determine the extent and location of gated communities. Although some of the information is outdated, it provides indications of the distribution of different types of gated communities in South Africa at that time.

${ }^{6}$ The survey did not define enclosed neighbourhoods and thus officials may have misunderstood the terminology.

of fragmentation, the urban morphology and social dynamics of each city vary greatly, as does their impact on each city's experience of private gated developments. However, the aim is not to present a detailed analysis of each city, but rather to highlight a few issues that are likely to contribute to each city's experience of gating.
}

\section{Population Dynamics}

Johannesburg, Durban and Cape Town are three of South Africa's key metropolitan areas, all hosting at least three million people, and located in the provinces of Gauteng, KwaZulu-Natal and the Western Cape, respectively. The City of Johannesburg is the largest municipal area in the country and is the financial hub of South Africa, while Durban (part of the e'Thekweni metropolitan area) is the next largest city and is defined by its large and busy port, with Cape Town functioning as the country's oldest urban settlement, parliamentary capital and tourist locus.

In addition to their diverse roles in South Africa, each city also comprises vastly different population dynamics. The metropolitan area of Johannesburg is dominated by Black Africans, comprising $73 \%$ of city population, but is also popular with Whites, $16 \%$ of the metropolis (they comprise only $9.6 \%$ of national population) but less popular with Coloured (6\%) and Indian (4\%) communities (Census 2001). ${ }^{7}$ Johannesburg's demographics illustrate the history of the city as a 'white' industrial zone with significant Black African labour in close proximity. However, since the end of apartheid, Johannesburg has witnessed significant growth in its Black African middle class, albeit alongside vast swathes of continued Black African poverty.

Durban's dual-demographic history, representing the 'home' of both Zulu and Indian South African heritage continues to reflect the city's population, dominated by the Black African population group (68\% of Durban), but also hostingsignificant Indian (20\%) and White (9\%) communities, alongside a handful of Coloured (3\%) residents (2001 census). In contrast, Cape Town's demographics are unique in not accommodating a Black African majority (only 32\% of Cape Town's population but $79 \%$ in South Africa), but an almost Coloured majority (48\% in Cape Town, 9\% nationally), and relatively dominant White minority (19\%) (2001 census). These demographics are a consequence of Cape Town's heritage as the Coloured population's birthplace ${ }^{8}$ and the absence of any proximate Black African 'bantustan' during apartheid.

The population dynamics of Johannesburg, Durban and Cape Town thus indicate the diversity of each city, with Black Africans dominant in the former two only, while Whites are primarily attracted to Johannesburg and Cape Town, Coloureds to Cape 


\footnotetext{
${ }^{7}$ The 2001 census is South Africa's most recent comprehensive population data. Although mid-year population estimates are released each year, they do not provide data at the city level. The next full census is planned for 2011.

${ }^{8}$ The Coloured population group developed as a consequence of mixed unions between Dutch settlers and Malay slaves, and between the Dutch and indigenous people (Khoikhoi, San, and later Xhosa) and slaves imported from West Africa (Welsh 1998; Were 1974).
}

\section{Apartheid History}

Apartheid ideology was an important influence on the growth, structure and urban development patterns of South Africa's cities. Apartheid was built on spatial divisions; separateness was taken literally to mean that Whites and blacks were divided into different residential areas in the city (Tomlinson et al. 2003). During apartheid, the city was exclusively White, with blacks considered 'temporary sojourners'. Black Africans, Coloureds and Indians were forced to settle in or were relocated to 'townships' on the urban periphery. The government produced rows of identical ('matchbox') houses in these dormitory areas, rarely accompanied by adequate engineering services, social infrastructure or parks and open spaces. Consequently, townships (to the south in Johannesburg and Durban, and southeast in Cape Town) remain marginalised areas with weak local economies, highly dependent on the rest of the city for employment, basic commodities and services. In contrast, more affluent White suburbs (to the north in Johannesburg and Durban, and to the north and south in Cape Town) grew and diversified. The expansion of White suburbs was characterised by homeownership and commuting by motorcar. The result was residential polarisation and growing inequalities between the city's White and black spaces (Beall et al. 2002).

In Cape Town this was exacerbated by Coloured labour preference, thus excluding Black Africans from the city, with no nearby 'homeland' and limited township space. ${ }^{9}$ The presence of the Coloured population group ensured that White residential areas were far removed from Black African areas, using railway lines and Coloured group areas as buffer zones (Cook 1991, 1992). Thus, Cape Town's White population were more secluded throughout apartheid than in other cities, with significant spatial and social distance from other races, particularly Black Africans.

\section{Post-apartheid Reconstruction of the City}

With the demise of apartheid in the late 1980s and repeal of the Group Areas Act in 1991, the post-apartheid era saw a reorganisation of space in South Africa's cities. However, the degree of change varied.

Both Johannesburg and Durban's post-apartheid changes have been characterised by a growing Black African middle class moving out of former township areas into inner-city suburbs, thus eroding the entrenched racial and class divisions of apartheid. The character of these inner cities has changed, accommodating migrants from the 
rest of Africa, perceived to be involved in drug trafficking and prostitution. This Africanisation (and consequent degradation) of the CBD in both Durban and Johannesburg expedited White and business flight, especially in the early postapartheid years (Beavon 2000). Consequently, further expansion to the north in both cities occurred in the form of large shopping malls, new gated industrial parks (combining offices and factories), secure office parks (campus-style developments in park-like surroundings) and secure townhouse complexes (gated, compact housing developments). This northbound sprawl represents the (predominantly White) flight

\footnotetext{
${ }^{9}$ The 1955 Coloured Labour Preference Act (repealed in 1985) legislated employment priority to Coloureds. Black Africans were only admitted to Cape Town for labour purposes provided unemployment was low.
}

of middle-class residential and business interests to newly created or re-inscribed suburbs, creating new 'edge cities' of Sandton in Johannesburg as well as Hillcrest and Umhlanga in Durban. ${ }^{10}$ The need for infrastructure support in these new suburbs thwarts the concomitant need for CBD renewal. Thus, a focus on the CBD and its (predominantly poor) populous by city management and politicians is in direct conflict with (predominantly wealthy) business, developers and citizens' focus towards Johannesburg and Durban's outlying areas. ${ }^{11}$

In contrast, Cape Town's urban transformation since the demise of apartheid has been minimal; indeed the city's apartheid-enforced structure remains dominant. Residential movement has been constrained by the strong private property market in former White areas, alongside Cape Town's unique demographics, ensuring a tiny black middle class. Furthermore, post-apartheid housing for low-income groups (predominantly black), have almost exclusively been situated on available and affordable land on the urban periphery, thus perpetuating apartheid city geography. Thus, despite some desegregation in middle-class suburbs (Saff 1998), and 'greying' between Whites and Coloureds in less prestigious former White areas, the overwhelming experience is of continued segregation, along both class and race lines. Furthermore, similar to Johannesburg and Durban, private residential, commercial and business development in contemporary Cape Town are concentrated in the northern (e.g., Century City, Tygervalley centre, Cape Gate centre) and southern (e.g. Claremont redevelopment) regions, both former White areas that benefited from apartheid's skewed distribution of resources; while investment in poor (former black) southeast areas has been virtually nonexistent despite state attempts (Turok2001). ${ }^{12}$

In addition, the topology of the city has determined post-apartheid development. While Cape Town is constrained by Table Mountain to the west and the ocean to the south, and Durban by the south coast, Johannesburg is theoretically free to expand in all directions, ${ }^{13}$ leading to significant sprawl and increased capacity for private developments in 'new' areas. Furthermore, since the demise of apartheid all three cities have witnessed growing numbers of informal settlements on vacant land within the city and along the boundaries of townships and in peri-urban areas (Saphire, cited in Beall et al. 2002), in contrast to the wealth and opulence of private developments. Implicit in these spatial transformations is the rising residential fragmentation of South Africa's metropolitan areas (Tomlinson et al. 2003). 
${ }^{10}$ Brodkin (1989) defines White flight as a process whereby 'Whites' and capital moved from urban centres to suburban environments in the USA after World War II. In reference to Durban, Freund and Padayachee (2002) emphasise that this is not solely race-bound but represents a general class movement toward an 'edge' centre surrounded by newly located businesses, retail and other lifestyle amenities.

${ }^{11} \mathrm{CBD}$ developments have focused on generating tourist revenue or providing exclusive and fortified condominium residences rather than constructing pro-poor developments, thus providing competition for the new edge city.

${ }^{12}$ For example, the 1996 Metropolitan Spatial Development Framework (MSDF) sought to create an economic node in Philippi (on the southeastern city edge) and link it with existing economic nodes in the southern and northern suburbs through the creation of an 'activity corridor'.

${ }^{13}$ Technically, Johannesburg is limited by restrictions placed by the 'urban edge' and unsuitable soil conditions in some areas (related to mining). However, urban sprawl is more possible than in Durban and Cape Town.

\section{Emergence of 'Gated Communities'}

\section{Fear of Crime}

Fear of crime and high crime rates are recognised as key reasons for gating throughout world. Although Johannesburg is viewed as the "crime capital of South Africa" (Palmery et al. 2003), all three cities suffer from high crime and problematic global images as perilous places. Insecurity is as much about the fear of crime as about crime itself, and the fear of crime can mask other fears and insecurities, such as the fear of race and social difference (Beall et al. 2002; Lemanski 2006b). However, whatever fears are based on, and whether rational or unfounded, they do have a significant impact on residential actions (Lemanski 2006b).

Residential burglary increased dramatically (by 38\%) in South Africa from 1994 to 2002 (SAPS 2003) ${ }^{14}$, and despite significant decreases from 2001 to 2006 (when residential burglary reduced by $13 \%),{ }^{15}$ the extent of property crime remains significant. Although some fluctuations are attributed to an initial post-1994 rise in reporting, the reality of everyday crime is confirmed by the 2003 national crime survey (Omar 2004). ${ }^{16}$ According to the survey, almost one quarter (22.9\%) of South Africans had been victims of crime in the preceding year, particularly property crime. Given this rising crime, South Africans have responded by increasingly securing their homes (e.g., alarms, high walls) in addition to enclosing their streets, while developers responded by constructing gated communities with additional security provision.

Durban and Johannesburg were South Africa's first cities to manifest gated communities in the early 1990s, while gated communities have only been popular in Cape Town for the past 5-7 years. This delay is a dual consequence of reduced levels of crime experienced by Cape Town's suburban residents, alongside the city's geography of significant spatial distancing between different people-groups and areas. Unlike Johannesburg, where Alexandra township has always bordered the upmarket suburb of Sandton, in Cape Town such poverty and wealth are distanced by the topology of the city and the legacy of apartheid buffers (especially the use of Coloured areas). However, in the mid- to late 1990s, personal and property crimes began to encroach into Cape Town's previously protected 'White' suburbs, and wealthy suburban residents began to consider the benefits of living in a more secure environment. 


\section{Enclosed Neighbourhoods}

The City of Johannesburg has by far the highest prevalence of enclosed neighbourhoods in South Africa. City officials indicated in 2002 that the majority of enclosed neighbourhoods occur in the northern suburbs, with the exception of

\footnotetext{
${ }^{14}$ The year 1994 is used as a base year for comparison because the South African Police Service (SAPS) began releasing comprehensive and reliable crime statistics at national and local levels in that year. Comparison is made to crime figures in 2001/2002 because these were the first statistics released for some time after the moratorium on crime data (only lifted after legal action by the media).

${ }^{15}$ Statistics from Institute for Security Studies [www.iss.co.za]. Released 27 Sept 2006.

${ }^{16}$ This is the most recent national crime survey undertaken.
}

Alberton in Johannesburg South. In contrast, there were very few enclosed neighbourhoods in the Central Region, which had the highest property crime rates. This can be partly explained by two factors. Firstly, the presence of other types of gated communities in the city centre such as secure office parks, townhouse complexes and high-rise apartments. Secondly, the average income per area and consequent housing needs: enclosed neighbourhoods are popular in middle-class suburbs with land space and organisational capacity among residents (e.g., time availability), while the city centre's lower-middle- to low-income population require more suitable housing (e.g., apartments). This suggests a positive relationship between enclosed neighbourhoods and middle- to higher-income areas, a trend evident throughout the world.

However, unlike Johannesburg, where residents have erected boom gates to control and limit access into already-established suburbs, enclosed neighbourhoods are extremely rare in Cape Town and Durban. This difference is a consequence of the different legal processes in Durban and Cape Town, indeed enclosed neighbourhoods are illegal in the former and costly and time-consuming in the latter. Unlike Johannesburg, where enclosed neighbourhoods remain public land (i.e. serviced by the municipality), in Cape Town, restricting access to your road/suburb requires taking full financial responsibility for all the services (e.g. refuse, stormwater drainage), as the municipality will not maintain an area now considered 'private' (van der Westhuizen 2006). Not surprisingly then, the relative ease of moving to a security estate, in which the private developer has already secured municipal approval, rather than embrace the financial, time and administrative burden of enclosing one's neighbourhood, has resulted in the dominance of security estates in Durban and Cape Town.

\section{Security Estates}

Although enclosed neighbourhoods are popular in Johannesburg, security estates are equally prevalent, largely in the same regions, i.e. the northern suburbs in addition to Alberton. Again the explanation is similar, with type of gated community and average income playing an important role, in addition to crime. Not surprisingly, secure highrise apartment blocks are prevalent in inner-city areas, while enclosed neighbourhoods and security estates are prevalent in middle- to upper-income suburban areas. Similar 
spatial trends are evident in Durban and Cape Town, with the majority of security estates located in wealthy areas both on the urban edge (the northern regions in both cities) in addition to preexisting middle-class areas (e.g., Cape Town's southern suburbs, and Musgrave and Morningside in Durban). However, the northern part of Durban is unique in that the majority of security estate development has been masterminded and undertaken by a single property developer, Moreland, a subsidiary of the Tongaat-Hulett Group (one of the largest sugar manufacturers in the world) who own the majority of land in the northern region of Durban and thus have a virtual monopoly on development in this area. In addition, there are a large number of gated community developments marketed as 'eco-estates' to a population seeking exclusion and connection to an ecological ethos and romanticism.

Only 10 years ago, the majority of this area comprised sugar cane fields with scattered beach towns and settlements. The areas around Umhlanga and Beloti are now surrounded by gated communities, huge malls, business parks, eco-estates, a new casino and a forthcoming airport that will change the entire dynamics of the city, all built on Tongaat-Hulett land. This redevelopment of Tongaat-Hulett's sugar cane fields has stimulated corporate and retail growth in the area. The 'largest shopping mall in the southern hemisphere' (www.gatewayworld.co.za) now adjoins the largest gated estate in the area, Mt. Edgecombe, in addition to several business parks. Thus, the land north of Durban has become the city's prime area of expansion, with Moreland now "the largest developer of real estate in KwaZulu-Natal” (Freund and Padayachee2002).

\section{Causes of 'Gating'}

In both types of gated communities, enclosed neighbourhoods and large security estates, high levels of crime were an important driver, although it appeared that fear of crime played a more significant role. A resident from an enclosed neighbourhood in Johannesburg explained:

Especially at night, when you reversed out of your driveway and got out to open the gate, there was a certain ... nervousness about ... [getting] mugged ... and ... [if I saw a] car's headlights behind [me] ... I would ... drive around the block to see how far this car was going to follow me ... You had that level of nervousness. $[1 \mathrm{H} 03 / 10 / 2003]^{17}$

This indicates the fear of crime prevailing in the neighbourhood beforeenclosure. Indeed, developers in all three cities promote security estates as offering a level of safety unavailable elsewhere in the city, and residents of enclosed neighbourhoods in Johannesburg base applications for access restriction on the need for security. However, other motivations for enclosing a neighbourhood were also presented; for example, the need for local management to combat the perceived inefficiency of the Council, and for the community to unite in a coordinated fashion to combat crime, especially as many local neighbourhoods had already done so.

Although rises in crime are the 'accepted' reason for the growth in gated communities and certainly the major precipitator for developers to begin constructing secure developments (in addition to strong financial returns); in fact, residents report much wider reasons for residing in a security estate. Despite 'security' being the most common reason given by residents of security estates in Cape Town, it was not just about 
protection from crime, but the provision of an idyllic village lifestyle for their family. ${ }^{18}$

This place is the lifestyle I dreamed of for my children: we don't have to lock the door, children just come in and play... We leave our children on their own and it's fine [M J-P 09/03/04]

Thus, although physical security is a crucial factor in residents' decision to move to a security estate, particularly given the perceived failure of the state in fighting crime, security provision per se is not the reason residents relocate (citizens can provide their

\footnotetext{
${ }^{17}$ To protect the identity of interviewees, each quote is coded, alongside the date of the interview.

${ }^{18}$ Obviously there were also contextual reasons specific to respondents' situation (e.g. work relocation, children's schooling).
}

own security in a non-gated suburb), but the lifestyle security estates offer. By transferring responsibility for physical security to an outside agency (the developer and security company), residents are able to function within an idyllic crime-free world, released from the concerns of security provision. Living in a security estate is therefore a lifestyle choice rather than a security choice. This links with Richard Ballard's (2004) understanding of gated communities as a form of "semigration" from South African society, as well as Hook and Vrdoljak's (2002) interpretation of gated communities as the means for citizens to divorce themselves from civic responsibility. However, the extent differs according to context. While residents of gated communities in all three cities expressed security as a motivating force, there appeared to be a concentration differentiation between cities. For example, residents of security estates in Johannesburg identified crime and associated fears as the dominant factor, with financial investment, a specific lifestyle, proximity to nature, community cohesion and social control only secondary motivations. In contrast, residents of security estates in Cape Town identified their prime motivation as creating a utopian lifestyle, reminiscent of a bygone era, protected and detached from the harsh realities and broader concerns of the outside world rather than about crime or economics per se (as in Johannesburg). That is not to suggest that crime no longer plays a role, but rather, that respondents in Cape Town attributed it as only a contributory factor, subordinate to creating an idyllic village environment, while respondents in Johannesburg identified crime as the dominant factor. Reasons for gating in Durban are situated somewhere between the extremes of Cape Town's idyllic lifestyle emphasis and the importance of crime protection in Johannesburg, with rationalisations offered for living in a gated estate ranging from investment opportunities, to a romantic association with a past time of 'safe living' replete with some form of community cohesion, and the omnipresent fear of crime that marks contemporary post-apartheid South Africa (Durington 2006).

\section{Current Trends in Urban Gating}

The growth of gated communities in South Africa's cities is of mounting concern to urban planners, local government and excluded citizens alike. What commenced in Johannesburg as a random patchwork of occasional gated zones is becoming the 
dominant experience as one traverses the South African city. Indeed, in the absence of a unified national, regional or local mandate gating has become a central feature of the post-apartheid city.

Although statistics on the exact number of gated communities are absent, with figures from the 2002 survey already obsolete, some general trends are evident. In Johannesburg, the Road Agency, responsible for dealing with applications for road closures, has on record approximately 600 enquiries regarding access restriction for security reasons. A recent survey by the City of Johannesburg indicated that there were 49 legal neighbourhood closures and 37 whose legality had expired, in addition to an estimated 188 illegal closures and 265 pending applications, ${ }^{19}$ indicating the numerical significance of neighbourhood enclosures.

${ }^{19}$ In terms of the Security Access Restriction Policy for the City of Johannesburg 2003.

Furthermore, in all three cities, the expansion of security estates is self-evident to the naked eye: empty tracts of land filled with cranes and billboards pronouncing the impending arrival of a 'luxury residential estate' with 'total security' abound in the post-apartheid city. Although initial gated development in Durban was controlled by the Moreland division of Tongaat-Hulett, other developers are now creating new estates throughout the metropolitan region. While the north of Durban continues to see the rapid proliferation of expansive gated golf estates such as Mt. Edgecombe, Zimbali and Simbithi, the Hillcrest section of the city is the new development 'hot spot', currently resembling a large construction site. In Cape Town, the transformation is made more noteworthy by the late arrival of gating in the city. However, the city is rapidly catching-up. According to a Cape Town municipal official, $80 \%$ of all new single residential development for high-income groups in the past 5 years have been gated and approximately $30 \%$ of all developments for middle- tolower-income groups (van der Westhuizen 2006). Furthermore, 5\% of all residential areas in Cape Town are situated in gated communities (Ibid.). Although this may seem relatively minor, the pace of growth is rapid.

As identified earlier, the principal debate regarding the presence of gated communities in urban environments centres on the privatisation of public space, in particular, concerns that gated developments function as private entities in the midst of otherwise public arenas and thus restrict basic human rights. The specific nuances of this public/private debate differ according to context.

In Johannesburg, the process of establishment differs significantly between security estates and enclosed neighbourhoods. The former are built on private land, often a greenfield site on the urban periphery, while the latter involve retrofitting an existing neighbourhood, usually in an older part of the city. Furthermore, security estates are established by private developers, who purchase the land, acquire development rights, develop the infrastructure (including gates and walls) and sell individual plots. In other words, it is an entirely private spatial entity in conceptualisation, development and ultimate residence. In contrast, enclosed neighbourhoods are established through a process of community mobilisation typically led by homeowner associations in obtaining the required percentage of residents' support, applying to the Council and managing the transformation of the existing neighbourhood. Thus, enclosed neighbourhoods remain public entities throughout their conversion from 'open' to 'gated'. The tensions and complexities both of erecting private estates within the boundaries of supposedly 'public' cities 
and also of enclosing (i.e., effectively privatising) a public residential area, in terms of perimeter fencing and access controlled boom gates, are addressed in the subsequent section.

In Cape Town, the situation differs slightly, albeit remaining focused on the public/private debate. Two principle types of residential gated community exist in Cape Town: 'prohibited access' and 'controlled access'. Much like security estates in Johannesburg, 'prohibited access' developments are private entities in which both the municipality and the general public have no responsibilities or rights. This is the dominant form of gated community in Cape Town's southern suburbs where land is limited and expensive. As with security estates in Johannesburg, residents (organised into a corporate body) are responsible for maintaining the roads and providing all internal services (e.g., refuse collection, storm-water drainage, street-lighting, road cleaning and maintenance). The high costs of maintenance ensure that such developments attract only the very wealthy. ${ }^{20}$ As this land is private, security guards have a legal right to prevent nonresidents from accessing the complex.

In contrast, 'controlled access' developments are public entities, functioning in the midst of Cape Town's policy void. Although private developers build the roads and sell properties/plots, the land remains public and thus the municipality services the complex (although residents often maintain specific aspects, for example public open spaces). This is the dominant form of gated community in the northern suburbs of Cape Town where land is abundant and the lower costs involved attracts professional couples, first-time homeowners and retiring down-scalers. ${ }^{21}$ As the land inside the complex is public, private security guards do not have a legal right to prevent nonresidents from gaining access, although most fail to abide by this, and thus the vast majority of gated communities in Cape Town operate as 'prohibited access' private estates in practice if not name.

Thus, whilst debates regarding the privatisation of public space are common to all three cities, the specific nuances differ.

\section{Impacts of 'Gating'}

The impact of gated communities in South Africa is schizophrenic; while some treat these spaces with disdain and hatred, others embrace their construction as a lifeline to a country drowning under the weight of crime and other social ills. The impacts of gated communities at both the neighbourhood and metropolitan level are thus considered.

\section{Inside the Gated Community}

Residents of gated communities in all three cities expressed increased feelings of safety as a result of fortification and access control, as well as an increased sense of community among those who supported the initiatives. However, it became evident through interviews with residents of security estates, particularly in Johannesburg and Tshwane, that this feeling of safety inside ironically contributed to greater anxiety outside, through the juxtaposition of the 'safe inside' versus 'dangerous outside'. 
This shows how physical space can influence social space or mental constructions of reality and also indicates the role gated communities play in exacerbating tensions between included and excluded citizens. This is particularly the case in Johannesburg, where crime is extremely high. Furthermore, although residents appreciate the sense of community and social control inside the estate, this can be taken to the

\footnotetext{
${ }^{20}$ Although specific figures vary according to the locations and services of the specific development, properties in all-private prohibited access developments in the southern suburbs retail for R3-5 million (approximately 250,000-415,000 GBP) with residents liable for a monthly levy of approximately R2,000 (approximately165 GBP).

${ }^{21}$ Properties in 'controlled access' developments in the northern suburbs retail for R0.7-1.3 million (approximately 58,000-107,000 GBP), and monthly levies are approximately R170-350 (approximately 14-29 GBP).
}

extreme, with some residents acknowledging total separation from the rest of the city and its residents. In this way, the estate starts to operate as a self-contained island, which may be viable socially, but not in terms of service provision (including water, electricity, sewerage removal and postal services), as well as access to food supplies and other goods, for which any security estate is still dependent on the rest of the city. This indicates the manner in which these private entities are encroaching, perhaps even superseding, public roles.

\section{Privatisation of Public Space}

Tensions arising from the private dominance of gated communities within public spheres of the city, its spaces and services, are common throughout the world. In Cape Town and Johannesburg, this tension is aggravated by the lack of public access to public land, in 'controlled access' developments in the former and enclosed neighbourhoods in the latter. Although neither gated communities have a legal right to exclude nonresidents, both do so, whether via physical gates and security guards or psychological perceptions of inaccessibility. One of the major criticisms levelled at gated communities worldwide is their exclusivity. This is usually justified by stressing their private nature, which is obviously an inadequate response when the land is in fact public, as with these two examples. As the roads inside both Cape Town's 'controlled access' developments and Johannesburg's enclosed neighbourhoods are municipal roads, the law provides access for all citizens. However, complex managers, developers and security providers rely on the ignorance of nonresidents to prevent complaints regarding exclusion. ${ }^{22}$

This privatisation of public space was also identified by the South African Human Rights Commission in 2005, which emphasised the legal implications of this exclusion, violating citizens' constitutional and human rights (SAHRC 2005).

\section{Socioeconomic Exclusion}

This lack of access and exclusion from public resources is further compounded by the racial and class composition of most gated communities. In Cape Town, residents of gated communities are predominantly White, a consequence of the city's demography and small black middle class. Although Johannesburg and Durban's gated communities have a slightly more mixed composition, a consequence of their 
growing Black African and Indian ${ }^{23}$ middle classes, respectively, they remain overwhelmingly class homogenous.

Thus, gated communities are criticised for perpetuating apartheid's Group Areas by enclaving Whites (alongside a handful of wealthy blacks) into exclusive spaces and lifestyles which the vast majority of (black) residents are unable to access. Residents of gated communities vehemently oppose this criticism arguing that

\footnotetext{
${ }^{22}$ In addition, the gatehouse in 'controlled access' developments is typically located on private land, and thus nonresidents are legally prevented from passing through the gatehouse, therefore preventing access to the public land that exists just beyond the private gatehouse.

${ }^{23}$ The fastest growing populations of gated community Durbanites are those of Indian descent. Taleb (2004) argues that the establishment of Indian, and particularly Muslim gated communities, indicates a desire to conform, but also to shelter one's identity from unwelcome influences.
}

there's nothing to stop anyone buying a house here" [P.H. 20/04/06] and stressing the presence of one or two black families in each complex. Whilst accurate that gated communities do not differentiate between black or White property purchasers, they do differentiate between wealthy and poor residents (only the former would be able to purchase property in a gated community), they are overwhelmingly populated by White families, and in Cape Town, they are predominantly situated in former White areas. Recognising these criticisms, gated developments in Durban have sought to sidestep the racial and class stereotypes levelled at them and their residents by re-creating themselves as 'eco-estates' that promote nature and conservation rather than economic superiority. Thus the 'acceptable' branding images of ecology and the environment are used to mask 'less acceptable' realities of class homogeneity and social exclusion.

Although South Africa's gated communities are criticised by nonresidents for representing a reinscription of apartheid due to their racial and class homogeneity, only benefiting a privileged view, many politicians recognise them as a necessary evil that provide jobs, a safe haven from crime and a temporary mechanism to curb emigration and capital flight. However, while the Human Rights Commission could not find any legal basis to deny the existence of security estates or road closures, their negative response stressed the retrenchment of class, and consequently racial, divisions that are established by their existence as neutralising any possible benefits (SAHRC 2005).

Interestingly, both their promoters and detractors stress the role of gated communities in a perverse political environment. While gated community residents emphasise the necessity of a new 'politicised Whiteness', manifest by moving into and defending these spaces, as a response to crime and perceived failure of the state to promote their interests, ${ }^{24}$ nonresidents criticise the state's acceptance and implicit legitimisation of wealthy enclaves, while the masses of South Africa remain homeless and poverty-stricken (Lemanski and Oldfield 2008). Ironically, neither group feels their interests are served by the political environment.

As long as South Africa's gated developments continue to be disproportionately located in wealthy regions and disproportionately occupied by White residents (particularly in Cape Town), they will continue to receive criticism for entrenching apartheid's social and spatial inequalities and divisions. In fact, the racial composition 
of gated communities ought to be irrelevant because irrespective of the race of residents, they do exclude nonresidents, often from public land. However, in the context of South Africa's dominant apartheid legacies, race remains a crucial indicator in the struggle for post-apartheid change, and thus local commentators consider their racial composition relevant.

\section{Impact on City Infrastructure}

The implications of a city characterised by a series of territorial enclosures for urban infrastructure and governance are immense. For example, large gated communities can impact the metropolitan area in numerous ways: physical (traffic congestion,

\footnotetext{
${ }^{24}$ This can also be witnessed in the proliferation of 'crime narrative websites' that have developed in recent years in South Africa that attempt to give 'real' stories of crime and often reference residence in gated communities as a last resort to save one's self and family from the realities of the "New" South Africa (Durington 2006).
}

road maintenance and spatial fragmentation), environmental (noise and air pollution), social (property prices, conflict and exclusion), urban management and maintenance (administration costs, service delivery and property taxes) and creating problems for neighbouring suburbs (regional domination, crime displacement).

Johannesburg's neighbourhood closures have led to changes in traffic patterns both inside and outside the area as a result of road closures. This has caused resistance from nonresident pedestrians and motorists now forced to use only boomed entrances and circumvent the entire area, respectively. This raises the issue of how to balance the opposing needs of safety for those inside versus accessibility for those outside. To a lesser extent, this is also a criticism of security estates in all three cities, which although not affecting preexisting traffic patterns (because they are new areas) do complicate traffic, as motorists are restricted to a decreasing series of roads sketching the perimeter of multiple developments.

Thus, gated communities are not entirely insular and harmless, as their residents claim, but have a profound effect on nonresidents, particularly those in close proximity. For example, the largest estate built by Moreland in Northern Durban essentially dictates the entire region, as the domestic labour population required for Durban's largest gated community have created informal settlements and contributed to township expansion on its edges. Indeed, Durban's estates are located around preexisting communities composed of diverse class and racial groups. While this could be interpreted as respecting preexisting communities, even if informal, in fact the plotting of gated communities appears more like an occupying strategy. Essentially, Moreland created gated communities in spaces that had the potential to become occupied by townships and informal settlements. Rather than allow this reclamation of black space, the establishment of gated communities inscribed these empty areas as White, or middle-class, space instead. Furthermore, the impenetrability of gated developments displaces crime into weaker, less protected areas, and thus, gated communities make rather poor neighbours (Lemanski 2006b). 


\section{Spatial Fragmentation}

One of the major criticisms of gated communities worldwide is their role in fragmenting the city into a succession of private citadels, leading to minimal engagement with people and public spaces outside the walls. This urban schism is both spatial, as the proliferation of developments ultimately divides the city into a series of bounded territories; and social, as residents of gated communities tend to be socially similar and function with limited outside contact. In South Africa, this fragmentation is augmented by concerns that gated communities not onlyexacerbate existing apartheid-legacy urban divisions, but also thwart national, provincial and city post-apartheid goals of integration and inclusion, particularly problematic given South Africa's vast inequalities.

This spatial fragmentation is particularly acute in Cape Town, where the rise of gated communities intensifies the city's existing urban morphology of separation between wealthy central-southern and northern areas (where gated communities are exclusively located) and distant areas of poverty in the southeast. Although arguable that by focusing private developments in these areas, the city is released to focus public funds on promoting residential and commercial developments in the povertystricken southeast, in reality, the success of private developments in the north and south serve to thwart post-apartheid public investment elsewhere by diverting resources, investment and attention to the city's preexisting areas of wealth (Turok 2001). Similar trends are evident in Johannesburg and Durban, albeit to a lesser extent, as despite gated communities' exclusive location in their northern regions, these areas also host poorer communities. However, this spatial proximity of different socioeconomic and racial groups is not matched by social or political integration as gated communities, by their very nature, separate themselves from the city and, as indicated earlier, have a negative impact on their neighbours (Lemanski 2006a, b).

These impacts also have an influence on urban design, planning and governance. For example, in Johannesburg the micro-fragmentation caused by gated communities (e.g., spatial division, social separation and the creation of strong micro-governments) arguably inhibits the post-apartheid planning goals promoted in the city's Integrated Development Plan (IDP) and Spatial Development Framework (SDF), which encourage integration, efficiency and equity, ${ }^{25}$ as well as increasing tension between different groups within the city. This also impedes egalitarian and social justice impulses, crucial to post-apartheid visions in all three cities.

\section{State Response to Gated Communities}

As identified, gated communities challenge urban governance and raise questions about how to balance the needs of specific communities against the needs ofbroader society to achieve a democratic system. Ultimately, the application of democracy at a local government level is questioned; democracy for those inside gated communities versus overall democracy in the wider city.

No national policy exists regarding gated communities, and cities differ in their levels of policy intervention. This policy void is compounded by a lack of agreement among local and national politicians. Those political parties in favour of gated 
communities, especially enclosed neighbourhoods, highlight the positive aspects, such as crime reduction, safe places for children to play, community involvement as well as minimising capital and human flight. Those against highlight the negative aspects, such as the adverse impact on service delivery, urban management and community cohesion on an urban scale. Although national government has begun to recognise these problems, indicated by President Thabo Mbeki's public scorn of gated communities and private golf estates (David 2005), his sentiments are diluted by the creation of a wall around Bryntirion estate, the official Pretoria residence of his top government officials (Sunday Independent 2007).

The dominance of enclosed neighbourhoods in Johannesburg, now a defining feature of the city, forced the local municipality to develop a policy to guide the application process. However, despite the equal dominance of security estates, no policy exists to monitor or control these private developments in Johannesburg. The enclosed neighbourhood policy was preceded by a lengthy process initiated by the different substructures of the former Greater Johannesburg Metropolitan Council

\footnotetext{
${ }^{25}$ For example, through the development of activity corridors and nodes, connecting and integrating mixed-use nodes with neighbourhoods and users.
}

(GJMC). ${ }^{26}$ Huge outcry from residents forced the Council to provide public hearings regarding such a policy, conducted in August and September 2003, which indicated that even within the local Council, there was no agreement. Eleven of the council departments and utility agencies gave presentations at the public hearings, four of which strongly objected, while the rest did not object provided that their recommendations were included in a new policy.

The subsequent City of Johannesburg policy gives guidelines regarding the structures of gates/fences/booms, stipulates the application fees and requires that $80 \%$ of all residents living inside a neighbourhood should be in favour of the road closures before the Council will consider an application. This policy was approved in April 2003, when the council also agreed that all illegally enclosed neighbour- hoods, as well as those whose permission had expired and had not reapplied, would be given 3 months grace to apply for permission to close off their neighbourhoods. After this period (end of July 2003), the Council proceeded to remove all known illegal enclosures within their jurisdictional area. ${ }^{27}$

In contrast, Durban and Cape Town have been less proactive in establishing an official response, partly because of the absence of neighbourhood enclosures and the normalisation of security estate applications within town-planning procedures for non-gated private developments, but also because of an absence of political will. However, September 2004 was a galvanizing moment as hearings by the South African Human Rights Commission brought many social and legal issues to a head, forcing municipal governments in both cities to consider uniform citywide responses to gated development applications.

Until recently, the political position of Durban metropolitan was not to 'officially' recognise gated developments, as they were essentially as illegal as informal settlements. Although ignoring their presence could be interpreted as an implicit acceptance of gated communities, in fact, Durban's city and municipal officials have an antagonistic relationship with gated community developers and residents. Residents and developers of gated communities repeatedly stress that the city, 
particularly the city manager, are 'enemies of estate development'. Indeed, in a recent city newsletter, the city manager expressed concerns that gated communities pose a threat to the ethos of the "New" South Africa (Lotter and Mteshane 2004).

In an interesting dualism, the city of Durban recently resorted to using both historical policies created under apartheid, and legislation from the post-apartheid constitution, to defend its anti-gating stance. Having observed the problems confronted by the city of Johannesburg and debates within Cape Town, Durban's city manager preempted many of these pro-gating arguments through a series of policy documents. Essentially, the municipality views these developments (and other attempts to enclose public space) on a descending scale of 'lesser evils' beginning with community patrols

\footnotetext{
${ }^{26}$ The GJMC was divided into four transitional local councils/substructures. Only two of these councils had a policy on neighbourhood enclosures-the EMLC and the NMLC. These policies made provision for the closure of existing roads on a temporary basis, for a maximum of 12 months (in accordance with the Rationalisation of Local Government Act 10, 1997, for Gauteng). As road closures were seen as a temporary measure only, the Council continued to be responsible for the maintenance of all roads and services.

${ }^{27}$ A huge task given that the Johannesburg Road Agency identified 553 illegal neighbourhood enclosures in July 2003.
}

working in conjunction with police, then controlled access points guarded byprivate security and, finally, gated community development as a last resort. The municipality defends its stance to control these developments by referring both to past laws, for example, a 1974 Ordinance establishing provincial council management of public streets to ensure universal public enjoyment of such spaces, in addition to current policy, in particular the constitutional right to 'freedom of movement and residence' (Lotter and Mteshane 2004). Thus, although gated community developments continue to proliferate throughout the Durban region, they are under the microscope of eThekwini municipality and the city manager. There are constant court cases involving the city against security companies and developers seeking to push the boundaries of aesthetic, infrastructure and design limitations established by the city.

Although Cape Town's officials were slow to respond to the challenge of gated communities, under the new DA-alliance, political will is at last forthcoming. The response is more neutral than Johannesburg's tacit acceptance of road closures and silence on security estates or Durban's vehement opposition. Until very recently, Cape Town's gated communities enjoyed implicit state acceptance, with officials and politicians expressing no concerns regarding their rise. The absence of a municipal policy ${ }^{28}$ was recognised in 2004 with the creation of a taskforce. However, several years of discussions amongst municipal officials and policymakers were fruitless. In September 2006, after a change in political control of the city, a steering committee was established, and in November 2006, an open 'hearing session' was held to discuss the development of a 'Secure Communities Policy' for Cape Town. Thus, the new DA-controlled metropolitan alliance finally initiated action after years of ANC stalling, and the 'Gated Development Policy' was released in November 2007 (with implementation from February 2008) (City of Cape Town 2007).

The hearing session implied tacit approval for gated communities, confirmed by the 2007 policy's focus on technical guidance for developer's applications (e.g. size of development, environmental and infastructural conditions) rather than opposing or constraining the continuation of such developments. However, the new policy does 
prohibit developments which privatise public space (i.e. enclosing roads serviced by the municipality) and requires all new developments to provide signage regarding public right of access. Although significant in recognising the rights of those "outside the gates', this merely legitimises the informal embargo on approving 'controlled access' developments that has operated in the Cape Town metropolitan area since early-2006 (Matthews 2006). Furthermore, developers will easily circumvent the policy by creating all-public estates in which entrance/exits are legally 'open' but appear 'closed' in terms of physical and environmental aesthetics (although the new information boards will mitigate this to some extent). A more significant feature of the policy is its failure to effectively regulate or prohibit all-private estates, thus mirroring the policy void regarding security estates in Johannesburg.

As highlighted, the policy environments and local state response differ significantly between the three cities, hardly surprising given their diverse histories and experiences of 'gating'. While Johannesburg implements a technocratic response to enclosed

\footnotetext{
${ }^{28}$ Although a Western Province policy on golf estates was developed as part of the Provincial Spatial Development Framework (PSDF), this has exclusively focused on rural areas and has not been implemented in the urban context of the Cape Town metropolitan area.
}

neighbourhood applications and Cape Town has just implemented a similar set of technical guidelines with tacit acceptance of private security estates, Durban has traversed a more antagonistic path, explicitly demonstrating city opposition to gated communities, albeit still using technical procedures (e.g., design infringements) to legally oppose them. Interestingly, Johannesburg is yet to initiate a systematic response to its security estates, and although Cape Town's prohibition of gated communities that effectively privatise space (i.e., controlled access) is a significant official change from the previous policy void, in fact, it merely legalises the previous informal embargo.

\section{Conclusion}

This research highlights the diverse experiences of residential gating in three South African cities. A focus at the city level allows the reasons, experiences and implications of these different experiences, situated in one country with a shared national history, to be explored. While axiomatic that different cities (and other scales) experience urban housing trends such as gated communities in diverse fashions, the literature tends to assume otherwise, particularly in South Africa where cities were almost uniformly altered by the application of apartheid's policies of extreme segregation.

Differences between each city exist in terms of the population demographics of gated community residents, the location of such developments in the city, the key motivations for residents choosing to gate, the types of estate that exist and their impact on the privatisation of public space and other consequences for the city, as well as differential municipal state responses in each city. Although differences also exist within each city, for example, between each gated estate; broad developmental trends and patterns can be identified at the city scale. Both qualitative and quantitative research conducted by the authors among residents of gated commu- nities and surrounding institutional entities demonstrates these multiple urban experiences. It 
has been shown that different institutions, contexts, histories, policy environments and city morphologies in each case contribute to diverse stories of gating, albeit with common themes. Particularly in South Africa, the impact on the social and spatial geography of each city, whilst varying in specifics, are in general facilitating and intensifying socioeconomic and spatial inequalities, closely tied to the racial inequalities institutionalised by apartheid. In essence, we conclude that while gating may be an individually rational decision in the context of South Africa's growing crime and fear of crime, its collective consequences produce a divided city, at odds with the post-apartheid ideals of unity and equality. Thus, the fashion in which South Africa responds to its gated developments has the ability (both symbolic and physical) to determine South Africa's future.

Worldwide, gated community environments represent the growing dominance of privatised spaces and services in the contemporary urban experience. Much of this expansion in privatisation is occurring in cities of the South, where the combination of rapidly expanding urban settlements ${ }^{29}$ alongside significant urban inequality ${ }^{30}$ is

\footnotetext{
${ }^{29}$ The majority of contemporary global urbanisation and urban expansion is concentrated in the global South, particularly Southeast Asia and sub-Saharan Africa (UNCHS 2006).

${ }^{30}$ The world's most unequal societies are concentrated in Latin America and sub-Saharan Africa, with South Africa's gini coefficient of 58 one of the highest in the world (World Bank 2006).
}

leading to the increased privatisation of all sorts of spaces (residential, business, recreational and commercial) and services (security and neighbourhood maintenance) to ensure a protected and well-serviced lifestyle for those with the financial means. In the global context of decreased public service coverage (as a consequence of increasing demand and limited resources) and the growing proximity of 'difference' (as a consequence of increased migration and polarised employment structures as a consequence of globalisation), the private sector has emerged as the dominant service provider and spatial controller. This has two significant impacts not captured by the overfocus on spatial fragmentation in the literature; firstly, the limited use of space and weak provision of services for those without financial means; and secondly, the decreased reliance on the state (in terms of services and local governance), and thus decreased willingness to submit to the state in other aspects of everyday life, amongst those with the financial means. Although such trends are evident in cities across the globe, each case deserves specific empirical and contextual analysis to unravel their homogenous treatment in both academic and common parlance.

Acknowledgement Charlotte Lemanski would like to thank and acknowledge the support of the Leverhulme Trust in funding her contribution to this research, which was conducted whilst a postdoctoral fellow at the Department of Environmental and Geographical Science, University of Cape Town. Matthew Durington would like to thank and acknowledge the support of the Mellon Foundation in funding his contribution to this research and the Department of Culture, Communication and Media Studies at the University of KwaZulu Natal.

\section{References}


Ballard, R. (2004). Assimilation, emigration, semigration and integration: 'White' peoples strategies for finding a comfort zone in post-apartheid South Africa. In N. Distiller, \& M. Steyn (Eds.) Under construction: 'Race' and identity in South Africa today (pp. 51-66). Johannesburg: Heinemann.

Beall, J., Crankshaw, O., \& Parnell, S. (2002). Uniting a divided city: Governance and social exclusion in Johannesburg. London: Earthscan.

Beavon, K. S. O. (2000). Northern Johannesburg: Part of the 'rainbow' or neo-apartheid city in the making?, Mots Pluriels, 13. [http://www.arts.uwa.edu.au/MotsPluriels/MP1300kb.html].

Beck, U. (1992). Risk society: Towards a new modernity. London: Sage.

Benit-Gbaffou, C. (2008). Unbundled security services and urban fragmentation in post-apartheid Johannesburg, Geoforum (in press).

Blakely, E., \& Snyder, M. G. (1997). Fortress America: Gated communities in the United States. Washington DC: Brookings Institution Press.

Bremner, L. (2004). Bounded spaces: Demographic anxieties in post-apartheid Johannesburg. Social Identities, 10, 455-468.

Brodkin, K. (1989). How Jews became white folks and what that says about race in America. New Brunswick: Rutgers University Press.

Caldeira, T. P. R. (1999). Fortified enclaves: The new urban segregation. In J. Holston (Ed.) Cities and citizenship (pp. 114-138). New York: Duke University Press.

Caldeira, T. P. R. (2000). City of walls: Crime, segregation and citizenship in São Paulo. California: University of California Press.

Census South Africa (2001). Stats SA: Pretoria. Accessed using: SuperTABLE 4.2 @ 1993-2003 SpaceTime Research Pty Ltd, Melbourne: Australia [http://www.str.com.au].

City of Cape Town. (2007). Gated Development Policy. Directorate: Strategy and Planning. Department of Planning and Building Development Management. 
Cook, G. P. (1991). Cape Town. In A. Lemon (Ed.) Homes apart: South Africa's segregated cities (pp. 2642). Cape Town: David Philip.

Cook, G. P. (1992). Khayelitsha: New settlement forms in the Cape peninsula. In D. M. Smith (Ed.) The apartheid city and beyond: Urbanisation and social change in South Africa (pp. 125-135). London: Routledge.

David, L. (2005). Speaking as a boomtown rat, Mail \& Guardian, 23 August 2005.

Davis, M. (1992). Beyond blade runner: Urban control—the ecology of fear, Open Magazine Pamphlet Series, 23, Open Media, New Jersey.

Durington, M. (2006). Race, space and place in Suburban Durban: An ethnographic assessment of gated community environments and residents. Geojournal, 66(1-2), 147-160.

Foldvary, F. (1994). Public goods and private communities. Aldershot: Edward Elgar.

Frantz, K. (2000). Gated communities in the USA-A new trend in urban development. Espace, Populations, Societies, 2000(1), 101-113.

Freund, B., \& Padayachee, V. (Eds.) (2002). (D)urban Vortex: South African City in Transition. Pietermaritzburg: University of Natal Press.

Glasze, G., Webster, C., \& Frantz, K. (2006). Introduction. In C. Webster, \& K. Frantz (Eds.) Private cities: Global and local perspectives (pp. 1-8). London: Routledge.

Hook, D., \& Vrdoljak, M. (2002). Gated communities, heterotopia and a "rights" of privilege: A 'heterotopology' of the South African security park. Geoforum, 33, 195-219.

Janoschka, M., \& Borsdorf, A. (2006). Condominios fechados and barrios privados: The rise of private residential neighbourhoods in Latin America. In C. Webster, \& K. Frantz (Eds.) Private cities: Global and local perspectives (pp. 92-108). London: Routledge.

Jencks, C. (1993). Heteropolis: Los Angeles, the riots, and the strange beauty of hetero-architecture. London: Ernst and Sohn.

Jürgens, U., Gnad, M., \& Bähr, J. (2003). New forms of class and racial segregation: Ghettos or ethnic enclaves? In R. Tomlinson, R. A. Beauregard, L. Bremner, \& X. Mangu (Eds.) Emerging Johannesburg: Perspectives on the post-apartheid city (pp. 56-70). London: Routledge.

Landman, K. (2000a). An overview of enclosed neighbourhoods in South Africa. Pretoria: CSIR.

Landman, K. (2000b). The urban future: Enclosed neighbourhoods, Urban Futures Conference, Johannesburg, South Africa.

Landman, K. (2003). Gated communities in South Africa: A national survey. Pretoria: CSIR.

Landman, K. (2004). Who owns the roads? Privatising public space in South African cities through neighbourhood enclosures, Privatisation of Urban Space, New Orleans.

Lemanski, C. (2004). A new apartheid? The spatial implications of fear of crime in Cape Town, South Africa. Environment and Urbanization, 16(2), 101-112.

Lemanski, C. (2006a). Spaces of exclusivity or connection: Linkages between a gated community and its poorer neighbour in a Cape Town master-plan development. Urban Studies, 43(2), 397-420.

Lemanski, C. (2006b). Residential responses to fear (of crime plus) in two Cape Town suburbs: Implications for the post-apartheid city. Journal of International Development, 18(6), 787-802.

Lemanski, C., \& Oldfield, S. (2008). 'The parallel claims of Gated Communities and Land Invations in a Southern City: Polarised State Responses', Environment and Planning A, (in press).

Lotter, K., \& Mteshane, L. (2004). Boom gates and road closures, eThekwini Municipality. [http://www. durban.gov.za/eThekwini/Municipality/municipality_news/boom_gates_road_closures].

Low, S. (1996). Spatializing culture: The social production and social construction of public space in Costa Rica. American Ethnologist, 23(4), 861-879.

Low, S. (2003). Behind the gates: Life, security and the pursuit of happiness in fortress America. London: Routledge.

Marcuse, P. (1997). The ghetto of exclusion and the fortified enclave. American Behavioural Scientist, 41, 311-336.

Madanipour, A. (2003). Public and private spaces of the city. London: Routledge.

Matthews, J. (2006). Interview on 12 April 2006, CEO of Garden Cities Corporation.

McKenzie, E. (1994). Privatopia: Homeowner associations and the rise of residential private government. New Haven: Yale University Press.

McKenzie, E. (2006). The dynamics of privatopia: Private residential governance in the USA. In C. Webster, \& K. Frantz (Eds.) Private cities: Global and local perspectives (pp. 9-30). London: Routledge.

Omar, B. (2004). Crime and safety in South Africa: Release of the 2003 national victim survey results, Is South Africa safer than in 1998? The ISS 2003 national victim survey provides some answers, Institute for Security Studies, Pretoria, 3 March 2004. [www.iss.co.za/Seminars/2004/0303sanvs.htm]. 
Palmery, I., Rauch, J., \& Simpson, G. (2003). Violent crime in Johannesburg. In R. Tomlinson, R.A. Beauregard, L. Bremner, \& X. Mangu (Eds.) Emerging Johannesburg: Perspectives on the post- apartheid city (pp. 101-122). London: Routledge.

Pretoria News (2006). SA emigrants flock to US, Australasia—stats, Babalo Ndenze, 20 November 2006.

Saff, G. (1998). Changing Cape Town: Urban dynamics, policy and planning during the political transition in South Africa. Lanham: University Press of America.

Salcedo, R., \& Torres, A. (2004). Gated communities in Santiago: Wall or frontier? International Journal of Urban and Regional Research, $28,27-44$.

Shaw, M. (2002). Democracy's disorder? Crime, police and citizen responses in transitional societies. Johannesburg: SAIIA Publication.

Shearing, C. D., \& Kempa, M. (2000). The role of 'Private Security' in transitional democracies, Crime and Policing in Transitional Societies: Comparative Perspectives Conference hosted by SAIIA, Johannesburg.

South African Human Rights Commission (SAHRC) (2005). Report on the issue of road closures, security booms and related measures. Pretoria: SAHRC. [http://www.sahrc.org.za/sahrc_cms/downloads/ Boomgate\%20Report.pdf].

South African Police Service (SAPS) (2003). South African Crime Statistics: released on 22nd September 2003, Criminal Justice Monitor, Institute for Security Studies, Pretoria. [www.iss.co.za/CJM/ stats0903/index.htm].

Sunday Independent (2007). Mbeki gets his wall but neighbours denied booms, February 25.

Taleb, N. (2004). Separation anxiety: Muslim identity and gated community development in Umhlanga, Master's Thesis, University of KwaZulu-Natal.

Tomlinson, R., Beauregard, R. A., Bremner, L., \& Mangu, X. (2003). Emerging Johannesburg: Perspectives on the post-apartheid city. London: Routledge.

Turok, I. (2001). Persistent polarisation post-apartheid? Progress towards Urban Integration in Cape Town. Urban Studies, 38(13), 2349-2377.

UNCHS (2006). State of the world's cities, United Nations Human Settlements Programme.

van der Westhuizen, J. (2006). Interview on 29 March 2006 and further correspondence. Land-Use Management, City of Cape Town.

Webster, C. (2001). Gated communities of tomorrow. Town Planning Review, 72(2), 149-170.

Webster, C., \& Glasze, G. (2006). Dynamic urban order and the rise of residential clubs. In G. Glasze, C.

J. Webster, \& K. Frantz (Eds.) Private cities: Local and global perspectives. London: Routledge. Welsh, F. (1998). A history of South Africa. London: Harper Collins.

Were, G. S. (1974). A history of South Africa. London: Evans Brothers Ltd.

World Bank (2006). World Development Indicators 2006. Washington, D.C.: World Bank. 